\title{
Habitat use of golden jackals (Canis aureus) in riverine areas of northern Bosnia and Herzegovina
}

\author{
Aldin Selimovic $^{1}$ (D) Eva Maria Schöll ${ }^{2}$ (D) Larissa Bosseler $^{2} \cdot$ Jennifer Hatlauf $^{2}$ (D) \\ Received: 29 June 2020 / Revised: 26 November 2020 / Accepted: 13 January 2021 / Published online: 27 January 2021 \\ (C) The Author(s) 2021
}

\begin{abstract}
Recently confirmed expansion of golden jackals (Canis aureus) into countries without any previous records poses questions, one of them focusing on the species potential and possibly varying habitat use. In this study, we investigated the presence and distribution of golden jackals in northern Bosnia and Herzegovina, where knowledge about golden jackal distribution and habitat use is still scarce. We used bioacoustic stimulation as a non-invasive tool to gather data on golden jackal presence. Habitat structures potentially selected by the species were assessed at 92 calling stations and used as input for binary logistic regression models. Our study area covered approximately $1150 \mathrm{~km}^{2}$, and bioacoustic stimulation within this area resulted in an estimated minimum relative group density of 3.5 territorial groups per $100 \mathrm{~km}^{2}$. We found territorial groups at distances between 15 and $38 \mathrm{~km}$ southwards from the river Sava but always within a maximum range of $3 \mathrm{~km}$ to perennial watercourses. Habitat analysis identified shrub vegetation and pastures as structures with a significant effect on the presence of resident golden jackals. Probability that golden jackals answered at calling stations increased with increasing surface area covered with pastures and shrubs. Distances between golden jackal territories and the nearest human settlement were relatively small. Our results indicate that structures like transitional woodland-shrubs and pastures, together with other potential influencing factors like local agricultural practices, low hunting pressure, diverse natural and anthropogenic food sources, could have benefited the settlement of golden jackals in the northern lowlands of Bosnia and Herzegovina.
\end{abstract}

Keywords Bioacoustic stimulation · CORINE land cover $\cdot$ GIS $\cdot$ Habitat analysis

\section{Introduction}

The golden jackal (Canis aureus Linnaeus, 1758) is a medium-sized carnivore which, considering its morphology and behaviour, is a typical member of the genus Canis (Clutton-Brock et al. 1976; Jhala 2004). Due to its tolerance to various types of habitats and its omnivorous diet, the golden jackal was able to colonize large areas in Europe (Trouwborst et al. 2015; Krofel et al. 2017). The distribution of this species in the Balkan region and its surroundings underwent

Eva Maria Schöll

eva.schoell@boku.ac.at

1 Research Institute of Wildlife Ecology, University of Veterinary Medicine Vienna, Savoyenstraße 1, 1160 Vienna, Austria

2 Institute of Wildlife Biology and Game Management (IWJ), University of Natural Resources and Life Sciences, Vienna (BOKU), Gregor-Mendel-Str. 33, 1180 Vienna, Austria significant changes in the twentieth century (Krofel et al. 2017); from a first expansion wave in the 1950s, with new records for example in Slovakia and Slovenia (Brelih 1955; Ferianc 1955) to a near extinction of the Pannonian population (Tóth et al. 2009), to massive resettlement in the Balkans and another wave of expansion to central and most recently northern Europe since the 1980s (Spassov 1989; Kryštufek et al. 1997; Tóth et al. 2009; Trouwborst et al. 2015; Krofel et al. 2017; Spassov and Acosta-Pankov 2019).

Knowledge about golden jackal distribution in Bosnia and Herzegovina $(\mathrm{B} \& \mathrm{H})$ is very scarce. Since there was no reliable data for this country, Arnold et al. (2012) assumed that at least vagrant individuals should be present. In Trouwborst et al. (2015), B\&H was listed as a country with reproducing golden jackal groups. Trbojević et al. (2018) confirmed resident golden jackals and observed an increase in hunting bag data between 2000 and 2016. Within their studied area in northern $\mathrm{B} \& \mathrm{H}$, golden jackal density was estimated to be a minimum of 0.33 groups per $10 \mathrm{~km}^{2}$. For the two neighbouring countries Serbia and Croatia, Śálek et al. (2014) estimated 1.1 and 0.9 
groups per $10 \mathrm{~km}^{2}$, respectively. In Bulgaria, densities as high as 2.83 groups per $10 \mathrm{~km}^{2}$ were recorded (Acosta-Pankov et al. 2018).

There are first indications that golden jackal core distribution is located along the Sava river in northern B\&H (Trbojević et al. 2018), but it still remains unclear, which variables drive jackal habitat selection. Therefore, the goals of our study were (1) to identify essential habitat structures for golden jackals in the riverine areas of northern $\mathrm{B} \& \mathrm{H}$ and (2) to analyse the distances of detected golden jackals to the nearest human settlement. We hypothesised that golden jackals can be confirmed near habitat structures that provide cover as well as protection from human persecution, e.g. shrubs or dense forests (Admasu et al. 2004; Giannatos et al. 2005; Šálek et al. 2014; Hatlauf et al. 2016). Secondly, we hypothesised that golden jackals can be detected in close distance, less than 1 kilometre, from the nearest human settlement (Macdonald 1979; Giannatos et al. 2005). Jackal occurrence was assessed with bioacoustic stimulation, a non-invasive and effective monitoring tool that has been used for surveys of several canids like African wild dogs (Lycaon pictus Temminck, 1820), grey wolves (Canis lupus Linnaeus, 1758) and golden jackals (Robbins and McCreery 2003; Giannatos et al. 2005; Comazzi et al. 2016; Hatlauf et al. 2017; Passilongo et al. 2017; Suter et al. 2017).

\section{Material and methods}

\section{Study area}

B\&H is a mountainous country dominated by Dinaric Alps with lowland areas positioned along the major rivers. Moving north from the central parts of $\mathrm{B} \& \mathrm{H}$, the landscape turns gradually into wide foothills and finally into lowlands. This area is characterized by a continental climate (Zurovec et al. 2015). Agricultural area makes $41.7 \%$ of the total surface area, and almost half of the arable land is left uncultivated. Less than $20 \%$ of the agricultural area, located mainly in the lowlands near the main river banks, is suited for intensive agriculture production (Volk 2010). Agriculture, in general, was massively influenced by the depopulation of rural areas induced by industrialisation (Zurovec et al. 2015). Small farms (up to $5 \mathrm{ha}$ ) represent about $80 \%$ of all agriculture farms. They are often split into more plots causing lower productivity and less efficiency. The most important crops are wheat and corn maize. Supported by the large proportion of grasslands in total (49\%), livestock production is an essential segment of B\&H agriculture (Volk 2010). The disposal of waste from livestock production is a commonly known problem in $\mathrm{B} \& \mathrm{H}$, with almost $4000 \mathrm{t}$ of animal tissue and $40 \mathrm{t}$ of dead fish disposed yearly. Such waste is being buried near production sites, disposed with regular waste or in the rivers and surrounding area (Meško et al. 2011).

The vast majority of our study area was located in the flatlands of the northern part of B\&H (Fig. 1) along the valley of the river Sava with minor parts in hilly regions at a maximum distance of $29.35 \mathrm{~km}$ southwards to the river Sava. The whole study area covered approximately $1150 \mathrm{~km}^{2}$ and stretched from the point where the river Sava enters B\&H in the north-west up to the border with Serbia in the north-east.

\section{Bioacoustic stimulation}

Bioacoustic stimulation was performed in August and September 2016 on eight nights at 92 sampling points (calling stations). August is being considered one of the months with higher possible answer rates (Acosta-Pankov et al. 2018). Linear survey transects were created southwards of the river Sava using a geographical information system (QGIS 2012, version 2.16.0) and according to accessible roads. Since Croatia and Serbia, both neighbour countries of B\&H, reported golden jackal presence (Kryštufek and Tvrtković 1990; Krofel 2008), our main and longest transect was positioned parallel to the border river Sava and contained 68 calling stations reaching from Donja Gradina in the north- west to the border with Serbia in the north-east. Furthermore, we positioned three short transects southwards from the main transect with the aim to inspect a potential dispersal of golden jackals towards areas with confirmed presence of grey wolves in central B\&H (Trbojević 2016). The first one was located between the cities Derventa and Kotorsko and was composed of 12 calling stations. The second one encompassed seven calling stations and was located in the area of the Majevica mountain (918 $\mathrm{m}$ above sea level). The third transect contained five calling stations and was located between the cities Ormanica and Gracanica. These three transects had less calling stations because of difficult terrain, bad road connections and lack of time and personnel. We systematically set up a total of 92 calling stations along these transects at regular intervals of 3-4 km, following Giannatos et al. (2005), assuming the maximum human hearing distance is $2 \mathrm{~km}$. Exceptions in the distance between single sampling points were made if cities or large villages interrupted the survey transect. In this case, calling stations were placed as close as possible, in front and after the interruption of the survey transect. In cases of landscape barriers like hills, the distance between calling stations was reduced to $1.5-2 \mathrm{~km}$, since we considered these to function as sound barriers as well.

We used a GPS device (Garmin Ltd., 8200 Schaffhausen, Switzerland) to locate the sampling points in the field. Sometimes a small correction had to be made if the planned location was inappropriate (e.g. high-traffic roads, houses with dogs, minefields). The exact coordinates of the calling 


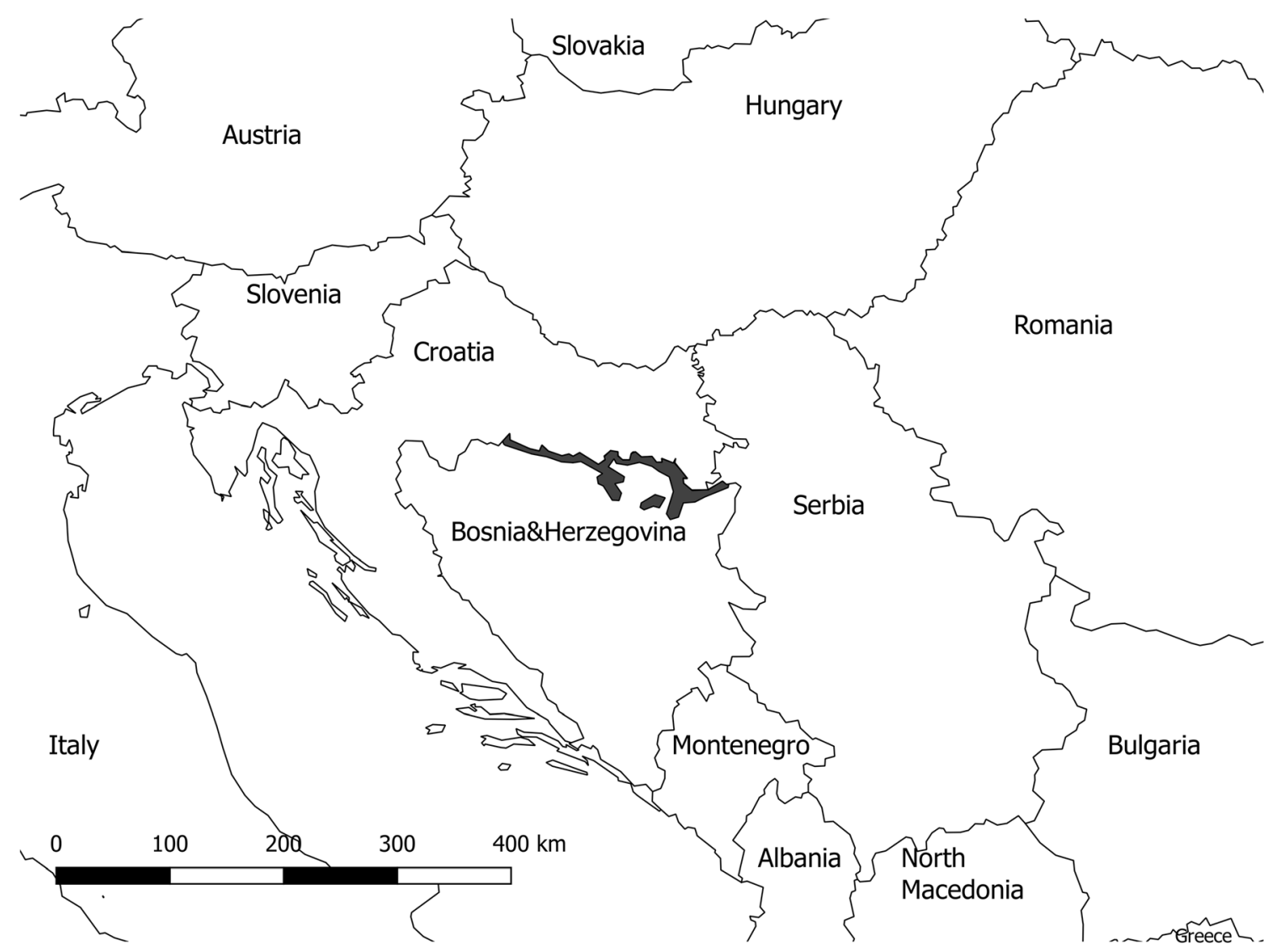

Fig. 1 Layout of the study area (dark grey) in northern B\&H (Country shape by Diva GIS)

stations were saved to the GPS device. Bioacoustic monitoring was performed on the sampling points to count individual answers or group answers to the call.

Howling audio tracks (calls) were emitted with a 60 W Megaphone (MEG060, Vexus audio, 7602 Almelo, The Netherlands). We arrived at the first calling station $15 \mathrm{~min}$ before sunset and started the playback $5 \mathrm{~min}$ after sunset. We approached the location of every following calling station by car, turned the engine and lights off, exited the vehicle, and waited $5 \mathrm{~min}$ before playing the first track from the megaphone. The emitted tracks were recordings of a group of golden jackals (group call) and a single dominant male golden jackal (single call). The group call was played first, followed by a single call and lastly the group call again. A break of 5 min was kept between each of the three tracks to allow the audition of answer calls. At each calling station, we noted the following information: coordinates, date, time, type of answer (individual answer or group answer/s), direction of answer call/s, weather conditions, and additional information about potential sources of disturbance that could affect the audio monitoring (traffic, dogs barking, etc.). We assumed that groups that react to acoustic stimulation are territorial, as described by Giannatos et al. (2005).

\section{Habitat analysis}

The exact locations of all 92 calling stations were uploaded into the geographical information system (ESRI ArcMap 10.4.1). Then, we created buffers around these single points to analyse and quantify features of the landscape within the defined distance of a $2 \mathrm{~km}$ radius, with an area of about $12.5 \mathrm{~km}^{2}$ that represents the possible home range size used by radio-tracked golden jackals (Giannatos 2004). Data on land cover types (see Table 1) were obtained from CORINE land cover 2012 (EEA 2018). We used the CORINE dataset as a classification of land cover types, but we did not verify these categories in the field, because landmine pollution did not allow detailed field observation within the whole study area. Finally, we quantified the spatial coverage of all land use categories (in $\mathrm{km}^{2}$ ) within the investigated 92 buffer areas.

\section{Data analysis}

To analyse the effect of land cover on occurrence of golden jackals, we created a binary logistic regression using the statistical software R (version 3.3.1, R Core Team 2016). The binomial response variable answer indicated that either an individual golden jackal or a group was heard, or no answer was received. Before analysing data, the explanatory variables 
Table 1 Overview and description of CORINE land cover (CLC) classes that are covering the study area. Variables in bold were finally included to analyse the habitat use of golden jackals (Heymann et al. 1994; EEA 2018)

\begin{tabular}{|c|c|c|}
\hline Acronym & CLC classes - Level 3 & Description \\
\hline discurban & 1.1.2 Discontinuous urban fabric & $\begin{array}{l}\text { Most of the land is covered by structures. Buildings, roads and artificially } \\
\text { surfaced areas associated with vegetated areas and bare soil, which occupy } \\
\text { discontinuous but significant surfaces. }\end{array}$ \\
\hline indust & 1.2.1 Industrial or commercial units & $\begin{array}{l}\text { Artificially surfaced areas (with concrete, asphalt, tarmacadam, or stabilized, e.g. } \\
\text { beaten earth) devoid of vegetation, occupy most of the area in question, which } \\
\text { also contains buildings and/or vegetated areas. }\end{array}$ \\
\hline nonirigated & 2.1.1 Non-irrigated arable land & $\begin{array}{l}\text { Cereals, legumes, fodder crops, root crops and fallow land. Includes flower and } \\
\text { tree (nurseries) cultivation and vegetables, whether open field, under plastic or } \\
\text { glass (includes market gardening). Includes aromatic, medicinal and culinary } \\
\text { plants. Excludes permanent pastures. }\end{array}$ \\
\hline pastures & 2.3.1 Pastures & $\begin{array}{l}\text { Dense, predominantly graminoid grass cover, of floral composition, not } \\
\text { under a rotation system. Mainly used for grazing, but the fodder may be } \\
\text { harvested mechanically. Includes areas with hedges (bocage). }\end{array}$ \\
\hline complexcult & 2.4.2 Complex cultivation & $\begin{array}{l}\text { Juxtaposition of small parcels of diverse annual crops, pasture and/or per- } \\
\text { manent crops. }\end{array}$ \\
\hline agrinatur & $\begin{array}{l}\text { 2.4.3 Land principally occupied by agriculture, } \\
\text { with significant areas of natural vegetation }\end{array}$ & $\begin{array}{l}\text { Areas principally occupied by agriculture, interspersed with significant } \\
\text { natural areas }\end{array}$ \\
\hline fruit & 2.2.2 Fruit trees and berry plantations & $\begin{array}{l}\text { Parcels planted with fruit trees or shrubs: single or mixed fruit species, fruit trees } \\
\text { associated with permanently grassed surfaces. Includes chestnut and walnut } \\
\text { groves }\end{array}$ \\
\hline \multirow[t]{3}{*}{ forest } & 3.1.1 Broad-leaved - forest & $\begin{array}{l}\text { Vegetation formation composed principally of trees, including shrub and } \\
\text { bush understories, where broadleaved species predominate. }\end{array}$ \\
\hline & 3.1.2 Coniferous forest & $\begin{array}{l}\text { Vegetation formation composed principally of trees, including shrub and } \\
\text { bush understories, where coniferous species predominate. }\end{array}$ \\
\hline & 3.1.3 Mixed forest & $\begin{array}{l}\text { Vegetation formation composed principally of trees, including shrub and } \\
\text { bush understories, where broadleaved and coniferous species co-dominate }\end{array}$ \\
\hline shrub & 3.2.4 Transitional woodland/shrub & $\begin{array}{l}\text { Bushy or herbaceous vegetation with scattered trees. Can represent either } \\
\text { woodland degradation or forest regeneration/colonization }\end{array}$ \\
\hline beach & 3.3.1 Beaches, dunes, and sand plains & $\begin{array}{l}\text { Beaches, dunes and expanses of sand or pebbles in coastal or continental, } \\
\text { including beds of stream channels with torrential regime }\end{array}$ \\
\hline marshes & 4.1.1 Inland marshes & $\begin{array}{l}\text { Low-lying land usually flooded in winter, and more or less saturated by water all } \\
\text { year round }\end{array}$ \\
\hline rivers & 5.1.1 Water courses & $\begin{array}{l}\text { Natural or artificial watercourses serving as water drainage channels. Includes } \\
\text { canals. Minimum width to include: } 100 \mathrm{~m}\end{array}$ \\
\hline lakes & 5.1.2 Water bodies & Natural or artificial stretches of water \\
\hline
\end{tabular}

were tested for multicollinearity by calculating variance inflation factors (Zuur et al. 2010). Since correlation between land cover variables within the buffers around single calling stations (radius $2 \mathrm{~km}$ ) was high (see Online Resource 1), and sample size within our study was limited ( $n=92$ calling stations), we had to remove variables before performing analyses. We excluded the following CLC classes from subsequent analyses: (a) beach, marsh, river and lakes, because most of our calling stations were located along the river Sava; (b) fruit, because only 4 out of the 92 calling stations were covered by the CLC class; and (c) indust and nonirigated, because they were highly correlated with discurban and complexcult, respectively (see Online Resource 1). We calculated a global model including the selected parameters and employed a multi-model inference approach (Burnham and Anderson
2002) to determine the most important variables. The covered surface area of land use categories (discurban, pastures, complexcult, agrinatur, forest, shrubs) and the distance to the nearest artificially surfaced areas (e.g. buildings, roads) were included as explanatory variables. Since calling stations were located in a riverine area, the mean distance to rivers was low (mean $\pm \mathrm{SE}=0.94 \pm 0.63$, range $=0.04-3.00 \mathrm{~km}$ ) and the variable was not included in the model.

A set of models with all possible combinations of fixed effects was generated (R package MuMIn, Bartoń 2020) and graded according to their Akaike's information criterion with a correction for small sample sizes $\left(\mathrm{AIC}_{\mathrm{c}}\right)$. A subset of models with $\triangle \mathrm{AIC}_{\mathrm{c}}$ of less than 2 was obtained and model-averaged coefficients were extracted. In addition, relative importance (RI) ranging from 0 (not included in any model) to 1 (included 
in all models) and $95 \%$ confidence intervals $(95 \% \mathrm{CI})$ of predictors were calculated to justify if parameter estimates are clear or inconclusive. Finally, we generated ROC curves and calculated the AUC values for the subset of models to test model discrimination. To visualize effects of CLC categories on occurrence of golden jackals, we performed separate simple logistic regression models and calculated predicted probabilities.

\section{Results}

\section{Bioacoustic stimulation}

Overall, we received golden jackal answers at 29 calling stations on a total area of $1150 \mathrm{~km}^{2}$, resulting in an estimated minimum relative group density of 3.5 territorial groups per $100 \mathrm{~km}^{2}$. Next to single howls $(n=7)$, we received answers from one up to four groups (mean $\pm \mathrm{SE}=1.8 \pm 0.24$ groups, $n=22$ ) at single calling locations (see Table 2), resulting in an overall sampling success effort of $31.5 \%$.

\section{Habitat characteristics}

Composition of land use types within the buffers around the calling sites was profoundly diverse (see Table 3 ). Areas within the 92 buffers were comprised of 2 to 9 different land use categories (mean $\pm \mathrm{SE}=5.7 \pm 0.16$ ). The vast majority of the studied area within buffers was covered by complexcult (24\%), forest (22\%), and nonirigated (20\%). Pastures and shrubs covered only smaller proportions of the study area but were present in almost half of the buffers surrounding the calling stations (pastures: $6.6 \%, n=46$ calling stations, shrubs: $2.5 \%, n=38$ calling stations). Indust, fruit, marshes, beach and lake covered only small proportions (each below $1 \%$ of the whole study area). Land cover types occurring in most of the buffers surrounding the 92 calling stations were forest $(n=86)$, agrinatur $(n=85)$ and complexcult $(n=84)$. Distance from all the calling stations to the nearest urban settlements ranged between 0.0 and $20.6 \mathrm{~km}$ (mean $\pm \mathrm{SE}=3.39$

Table 2 Number of calling stations with estimated number of groups

\begin{tabular}{ll}
\hline Estimated group count & N calling stations \\
\hline No answer & 63 \\
Single animal & 7 \\
One group & 13 \\
Two groups & 3 \\
Three groups & 3 \\
Four groups & 3 \\
Total & 92 \\
\hline
\end{tabular}

Table 3 Summary statistics of land cover types $\left(\mathrm{km}^{2}\right)$ which covered the area within the buffers (radius $2 \mathrm{~km}$ ) surrounding the 92 calling stations (according to CLC classification, see Table 1). Variables included in the GLM are highlighted in bold

\begin{tabular}{llcll}
\hline Variable & Minimum & Maximum & Mean \pm SE & Median \\
\hline discurban & $\mathbf{0 . 0 0}$ & $\mathbf{2 . 5 1}$ & $\mathbf{0 . 2 6} \pm \mathbf{0 . 0 4 5}$ & $\mathbf{0 . 0 1}$ \\
indust & 0.00 & 0.86 & $0.03 \pm 0.013$ & 0.00 \\
nonirigated & 0.00 & 9.68 & $2.49 \pm 0.275$ & 2.49 \\
pastures & $\mathbf{0 . 0 0}$ & $\mathbf{8 . 3 1}$ & $\mathbf{0 . 8 2} \pm \mathbf{0 . 1 7 7}$ & $\mathbf{0 . 0 1}$ \\
complexcult & $\mathbf{0 . 0 0}$ & $\mathbf{7 . 4 9}$ & $\mathbf{2 . 9 6} \pm \mathbf{0 . 2 1 6}$ & $\mathbf{2 . 8 4}$ \\
agrinatur & $\mathbf{0 . 0 0}$ & $\mathbf{6 . 4 1}$ & $\mathbf{2 . 1 3} \pm \mathbf{0 . 1 7 1}$ & $\mathbf{1 . 9 9}$ \\
fruit & 0.00 & 1.35 & $0.03 \pm 0.017$ & 0.00 \\
forest & $\mathbf{0 . 0 0}$ & $\mathbf{1 2 . 0 6}$ & $\mathbf{2 . 6 9} \pm \mathbf{0 . 2 5 6}$ & $\mathbf{1 . 9 5}$ \\
shrub & $\mathbf{0 . 0 0}$ & $\mathbf{2 . 0 7}$ & $\mathbf{0 . 3 1} \pm \mathbf{0 . 0 5 0}$ & $\mathbf{0 . 0 0}$ \\
beach & 0.00 & 0.22 & $0.00 \pm 0.002$ & 0.00 \\
marshes & 0.00 & 0.41 & $0.02 \pm 0.008$ & 0.00 \\
rivers & 0.00 & 1.92 & $0.58 \pm 0.060$ & 0.67 \\
lakes & 0.00 & 1.84 & $0.03 \pm 0.021$ & 0.00 \\
\hline
\end{tabular}

$\pm 0.389 \mathrm{~km})$. While the median distance to the nearest settlements was $1.68 \mathrm{~km}$ for negative calling stations, it was $3.1 \mathrm{~km}$ for the positive ones. The elevation at the chosen calling stations ranged between $77 \mathrm{~m}$ and $611 \mathrm{~m}$ above sea level.

The subset of models explaining occurrence of golden jackals in the study area with $\Delta \mathrm{AIC}_{\mathrm{c}}<2$ encompassed 3 models (see Table 4). The final averaged model included the variables pastures, shrubs, agrinatur, and forest. Discurban and complexcult were not useful predictors of occurrence of golden jackals. Probability that golden jackals answered at a calling station increased with increasing surface area covered with pastures (Estimate $\pm \mathrm{SE}=0.37 \pm 0.15$, RI: $1.00,95 \%$ $\mathrm{CI}=0.07,0.66$, see Fig. 2) and shrubs (Estimate $\pm \mathrm{SE}=$ $1.02 \pm 0.49, \mathrm{RI}=1.00,95 \% \mathrm{CI}=0.05,1.99$, see Fig. 3 ). The relative importance of agrinatur (Estimate $\pm \mathrm{SE}=0.19 \pm 0.16$, $\mathrm{RI}=0.33,95 \% \mathrm{CI}=-0.13,0.50)$ and forest (Estimate $\pm \mathrm{SE}=$ $-0.07 \pm 0.11, \mathrm{RI}=0.20,95 \% \mathrm{CI}=-0.28,0.14$ ) was low and confidence intervals included zero, indicating little evidence that these predictors affect occurrence of golden jackals. The AUC values of the 3 models in the subset ranging between 0.74 and 0.76 indicated a fair discrimination between calling stations with golden jackal presence and absence.

\section{Discussion}

The bioacoustic method was successfully applied to analyse the occurrence of golden jackals in the study area in northern B\&H (sampling effort success over 30\%). Within the 92 calling stations, 29 were positive, 22 from which we received answers of groups (seven single answers). We detected a total of 40 presumed territorial groups in the survey area (the 7 
Table 4 Subset of binary logistic regression models $(\triangle \mathrm{AICc}<2)$ explaining variation in the probability of golden jackal occurrence at the 92 calling stations, derived using dredge function (Bartoń 2020)

\begin{tabular}{lllll}
\hline Models & $\mathbf{A I C}_{\mathbf{c}}$ & $\mathbf{\Delta} \mathbf{A I C}_{\mathbf{c}}$ & $\mathbf{A I C}_{\mathbf{c}}$ weight & $\mathbf{A U C}$ \\
\hline$=\beta_{0}+$ pastures + shrubs & 110.5 & 0.0 & 0.48 & 0.75 \\
$=\beta_{0}+$ pastures + shrubs + agrinatur & 111.2 & 0.7 & 0.33 & 0.74 \\
$=\beta_{0}+$ pastures + shrubs + forest & 112.2 & 1.7 & 0.19 & 0.76 \\
\hline
\end{tabular}

single individual answers were not counted as a group). Minimum relative densities of territorial groups detected in this study are lower compared with those from northern Dalmatia (Krofel 2008), Peljesac peninsula (Krofel 2007), areas in Serbia and Romania (Š́lek et al. 2014) or Bulgaria (Acosta-Pankov et al. 2018). Based on information from local hunters and residents, northern Bosnia seems to be the core area of golden jackal occurrence in this country with most of the groups located along the river Sava, similar to the denser jackal areas in the lowlands around the Danube in Serbia (Śálek et al. 2014). One possible reason for a diverse occurrence pattern in Bosnia could be the absence of wolves in the lowlands of northern $\mathrm{B} \& \mathrm{H}$ that might, on the other hand, be the limiting factor to jackal presence in other parts of the Balkan peninsula (Kryštufek and Tvrtković 1990; Krofel et al. 2017; Newsome et al. 2017). Still, we achieved to confirm six groups of golden jackals with territories southwards the river Sava, the furthest being $37 \mathrm{~km}$ towards central B\&H. This dispersion could become a trend (southward) in the future due to habitat degradation by regular flooding events in the area along the Sava river (Boudaghpour et al. 2015).

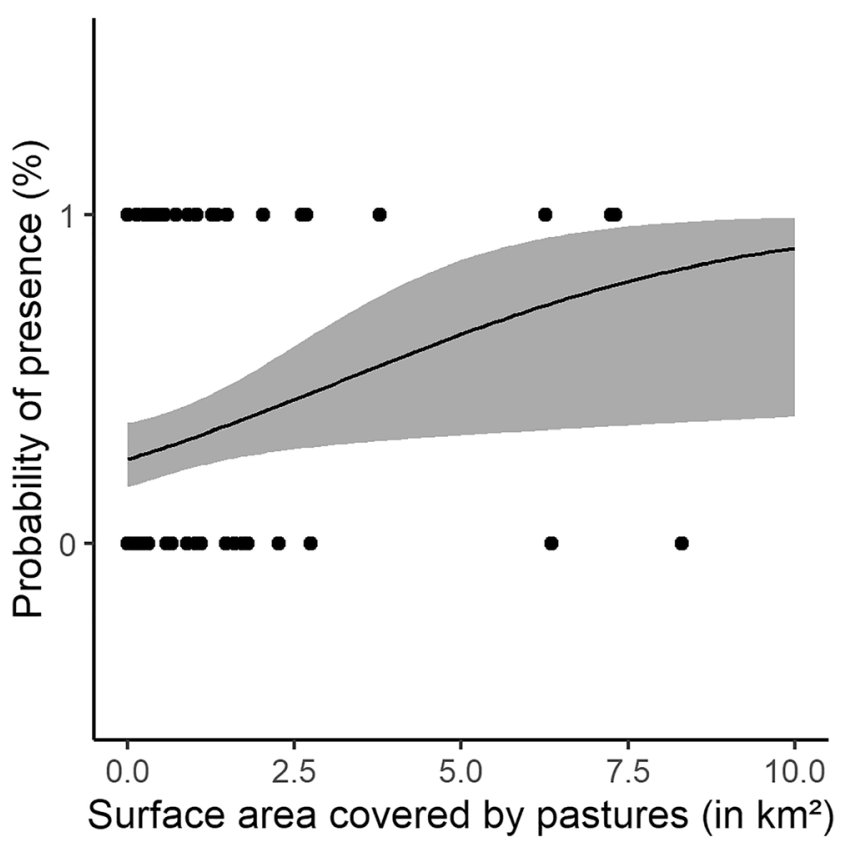

Fig. 2 The probability of golden jackal presence at calling stations was positively affected by pasture cover. For graphical illustration, simple logistic regression was performed (Estimate $\pm \mathrm{SE}=0.33 \pm 0.15, p=$ 0.025 ) and the predicted probability was calculated afterwards
Confirming our first hypothesis, the habitat analysis models show that areas covered with pastures and shrubs have a significant positive effect on the presence of golden jackals. Similar to previous habitat analyses from Serbia, that displayed an increased selection of shrubs as well, specifically when their coverage in the habitat was sparse (Šálek et al. 2014). The number of detected golden jackal groups decreased with an increasing proportion of arable land, whereas an increased presence of shrubs proved to influence golden jackal populations positively in Bulgaria (Š́alek et al. 2014).

Our study shows that with only a slight increase of shrubs in the surveyed areas, the probability of golden jackal presence increased strongly (Fig. 2). Hence, if the area of shrubs surrounding the calling stations doubles from $2 \mathrm{~km}^{2}(60 \%$ probability of presence) to $4 \mathrm{~km}^{2}$, the probability of golden jackal presence within this area rises to almost $100 \%$. The lowlands in northern Bosnia are mainly used for agricultural purposes (Witmer and O'Loughlin 2009), already indicating potential habitat for golden jackals. After the war in $\mathrm{B} \& \mathrm{H}$, which ended in 1995, almost $44 \%$ of the former arable land now lies idle (Volk 2010). Dense vegetation and single trees

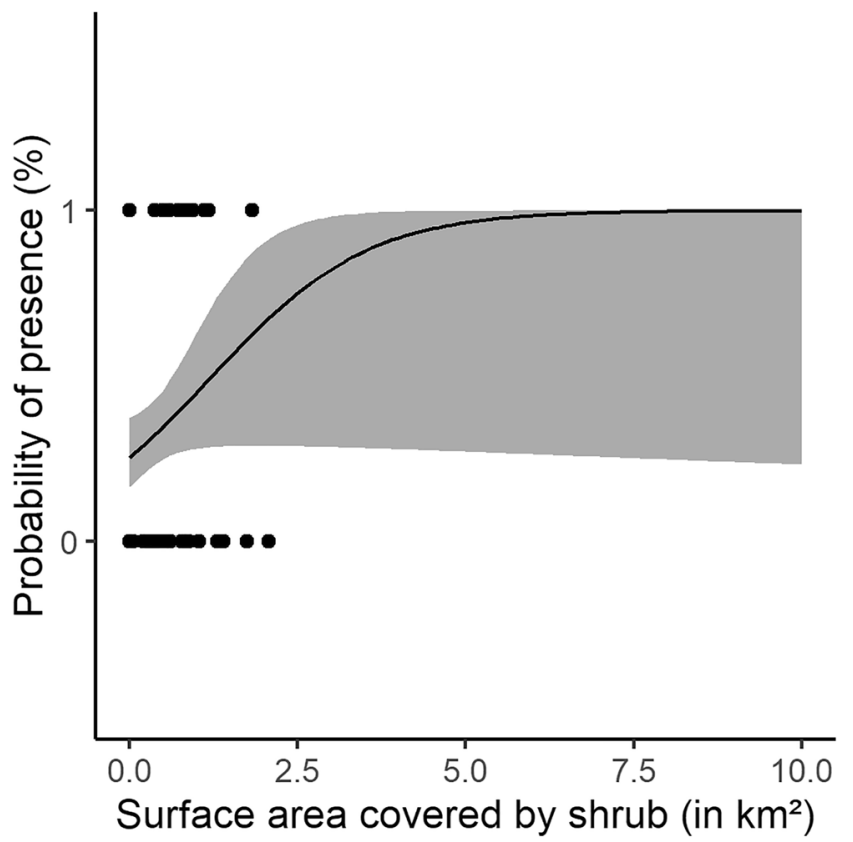

Fig. 3 The probability of golden jackal presence at calling stations was positively affected by shrub cover. For graphical illustration, simple logistic regression was performed (Estimate $\pm \mathrm{SE}=0.87 \pm 0.47, p=$ 0.062 ) and the predicted probability was calculated afterwards 
often overgrew these abandoned agricultural areas or have transformed into natural fallows (Witmer and O'Loughlin 2009; Volk 2010). Such habitats offer essential structures for golden jackals like thick cover for resting, hiding and building dens (Admasu et al. 2004; Giannatos et al. 2005). Furthermore, the species-rich natural pastures (Söderström et al. 2001; Hartel et al. 2013) as potential hunting grounds could be the reason why golden jackals seem to favour these areas. Anthropogenic food sources could explain the possible presence of golden jackals near human settlements, especially when shrub structures in the surrounding are present (Giannatos 2004). Our second hypothesis, regarding the possible detection of golden jackals within $1 \mathrm{~km}$ to human settlements, could be confirmed. Nevertheless, in more detail, our survey showed that while the median distance of negative calling stations was $1.68 \mathrm{~km}$, it was $3.1 \mathrm{~km}$ for positive calling stations. This result might indicate a tendency to a stronger avoidance of human settlements compared to other regions, at least within studied area.

Our results reveal that golden jackals in northern B\&H show preferences for habitat structures similar to those in surrounding countries. The shrub areas and pastures in the northern lowlands of $\mathrm{B} \& \mathrm{H}$ are a result of the agricultural policy and practices and seem to influence the presence of golden jackals positively by offering protection from humans (hunting pressure) and natural as well as anthropogenic food sources. Furthermore, the migration of the local population from rural areas, abandoned arable land, minefields, unsuitable hunting strategies, and improper waste management might represent further factors affecting the distribution of golden jackals in B\&H directly or indirectly. We suggest the acoustic stimulation to be used country-wide to create a holistic picture (overview) of the golden jackal's distribution and relative density. Although golden jackals generally respond throughout the year, for future studies, we recommend the late summer as the best season for field surveys (next to a peak in answers from January to March), as it was suggested in the study of Acosta-Pankov et al. (2018) performed in Bulgaria. At this time of the year, wind conditions at night are favourable (low or no wind) and vegetation offers more cover for researchers, therefore less detection by golden jackals and hence a higher possibility of positive answers. Nevertheless, precautions should be made to avoid habituation to bioacoustic stimulation. For this reason, we suggest not to search for animals that could potentially move towards the calling station with a torch, as with this practice jackals might associate the presence of humans with the playback calls and avoid answering them in future surveys. Although costly, thermal imaging devices may serve as an alternative. Additionally, random visits of calling stations, only twice a year, are likely to avoid habituation.

Supplementary Information The online version contains supplementary material available at https://doi.org/10.1007/s10344-021-01457-7.
Acknowledgements We would like to thank Nathan Ranc and Duško Ćirović for their advice during fieldwork.

Authors' contributions AS and JH conceived the original study, AS and LB performed fieldwork, and AS and ES performed the statistical analyses. AS, JH and ES wrote the manuscript.

Funding Open Access funding provided by University of Natural Resources and Life Sciences Vienna (BOKU). JH is a recipient of the DOC Fellowship of the Austrian Academy of Sciences at the Institute of Wildlife Biology and Game Management, University of Natural Resources and Life Sciences.

Data availability The datasets analysed during the current study are available from the corresponding author on reasonable request. The source dataset of land cover analysed during the current study are made available from the following location:

CORINE land cover: http://land.copernicus.eu/pan-european/corineland-cover/clc-2012/view

\section{Compliance with ethical standards}

Conflict of interest The authors declare that they have no conflict of interest.

Ethics approval Not applicable.

Open Access This article is licensed under a Creative Commons Attribution 4.0 International License, which permits use, sharing, adaptation, distribution and reproduction in any medium or format, as long as you give appropriate credit to the original author(s) and the source, provide a link to the Creative Commons licence, and indicate if changes were made. The images or other third party material in this article are included in the article's Creative Commons licence, unless indicated otherwise in a credit line to the material. If material is not included in the article's Creative Commons licence and your intended use is not permitted by statutory regulation or exceeds the permitted use, you will need to obtain permission directly from the copyright holder. To view a copy of this licence, visit http://creativecommons.org/licenses/by/4.0/.

\section{References}

Acosta-Pankov I, Spassov N, Banea O (2018) Seasonal differences in howling response of golden jackals Canis aureus L., 1758 (Mammalia: Canidae) in eastern Bulgaria. Acta Zool Bulgarica 79: 539-545

Admasu E, Thirgood SJ, Bekele A, Laurenson MK (2004) Spatial ecology of golden jackal in the Ethiopian highlands. Afr J Ecol 42:144152. https://doi.org/10.1111/j.1365-2028.2004.00497.x

Arnold J, Humer A, Heltai M, Murariu D, Spassov N, Hackländer K (2012) Current status and distribution of golden jackals Canis aureus in Europe. Mamm Rev 42:1-11. https://doi.org/10.1111/j. 1365-2907.2011.00185.x

Bartoń K (2020) MuMIn: Multi-Model Inference. R package version 1.43.17. https://cran.r-project.org/web/packages/MuMIn/index. html. Accessed 11 May 2020

Boudaghpour S, Bagheri M, Bagheri Z (2015) Estimation of flood environmental effects using flood zone mapping techniques in Halilrood Kerman, Iran. Arab J Sci Eng 40:659-675. https://doi.org/10.1007/ s13369-014-1536-2 
Brelih S (1955) Šakali (Canis aureus L.) na ozemlju Slovenije. Biol Vest 4:56-58

Burnham KP, Anderson DR (2002) Model selection and multimodel inference: a practical information-theoretic approach. Springer, New York

Clutton-Brock J, Corbet GB, Hills M (1976) A review of the family Canidae, with a classification by numerical methods. Bull $\mathrm{Br}$ Museum, Natural Hist 29:118-199

Comazzi C, Mattiello S, Friard O, Filacorda S, Gamba M (2016) Acoustic monitoring of golden jackals in Europe: setting the frame for future analyses. Bioacoustics 25:267-278. https://doi.org/10.1080/ 09524622.2016 .1152564

EEA (2018) CORINE land cover 2012 - version 18 5. Copernicus Land Monitoring Service. http://land.copernicus.eu/pan-european/corineland-cover/clc-2012/view

Ferianc O (1955) Príspevok k stavovcom Žitného ostrova I. Biológia Bratislava 10:308-324

Giannatos G (2004) Conservation action plan for the golden jackal Canis aureus L. Greece WWF. https://www.wwf.gr/images/pdfs/ jackalactionplan.pdf. Accessed 7 May 2020

Giannatos G, Marinos Y, Maragou P, Catsadorakis G (2005) The status of the golden jackal (Canis aureus L.) in Greece. Belg J Zool 135: $145-149$

Hartel T, Dorresteijn I, Klein C, Máthé O, Moga CI, Öllerer K, Roellig M, von Wehrden H, Fischer J (2013) Wood-pastures in a traditional rural region of Eastern Europe: characteristics, management and status. Biol Conserv 166:267-275. https://doi.org/10.1016/j. biocon.2013.06.020

Hatlauf J, Heltai M, Szabó L, Hackländer K (2017) Golden jackal (Canis aureus) occurrence in Austria: from first records to recent findings. 33rd International Union of Game Biologists Congress, IUGB, Montpellier 2017, 178

Hatlauf J, Suppan F, Hackländer K (2016) Der Goldschakal (Canis aureus, L.1758) - Status, Habitatfaktoren und Modellierungsansatz. Säugetierkundliche Informationen 50. Symposiumsband Säugetierschutz - Schutzbemühungen um die heimische Säugetierfauna. Jena:133-153

Heymann Y, Steenmans C, Croisille G, Bossard M (1994) CORINE land cover. Technical guide. Office for Official Publications of the European Communities, Luxembourg

Jhala YV (2004) Golden jackal (Canis aureus). Canids Foxes, Wolves, Jackals Dogs Status Surv Conserv Action Plan:156-161

Krofel M (2007) Golden jackals (Canis aureus L.) on the Pelješac peninsula (southern Dalmatia, Croatia). Nat Croat 16:201-204

Krofel M (2008) Survey of golden jackals (Canis aureus L.) in northern Dalmatia, Croatia: preliminary results. Nat Croat 17:259-264

Krofel M, Giannatos G, Ćirović D, Stoyanov S, Newsome TM (2017) Golden jackal expansion in Europe: a case of mesopredator release triggered by continent-wide wolf persecution? Hystrix It J Mamm 28:9-15. https://doi.org/10.4404/hystrix-28.1-11819

Kryštufek B, Murariu D, Kurtonur C (1997) Present distribution of the golden jackal Canis aureus in the Balkans and adjacent regions. Mamm Rev 27:109-114

Kryštufek B, Tvrtković N (1990) Range expansion by Dalmatian jackal population in the 20th century (Canis aureus Linnaeus, 1758). Folia Zool 39:291-296

Macdonald DW (1979) The flexible social system of the golden jackal, Canis aureus. Behav Ecol Sociobiol 5:17-38

Meško G, Dimitrijević D, Fields CB (2011) Introduction to understanding and managing threats to the environment in South Eastern Europe. NATO science for peace and security series C: environmental security, vol 2. Springer, Dordrecht. https://doi.org/10.1007/97894-007-0611-8_1

Newsome TM, Greenville AC, Ćirović D, Dickman CR, Johnson CN, Krofel M, Letnic M, Ripple WJ, Ritchie EG, Stoyanov S, Wirsing
AJ (2017) Top predators constrain mesopredator distributions. Nat Commun 8:15469. https://doi.org/10.1038/ncomms15469

Passilongo D, Marchetto M, Apollonio M (2017) Singing in a wolf chorus: structure and complexity of a multicomponent acoustic behaviour. Hystrix It J Mamm 28:180-185. https://doi.org/10.4404/ hystrix-28.2-12019

QGIS (2012) Quantum GIS geographic information system. Open Source Geospatial Foundation Project. http://qgis.osgeo.org

R Core Team (2016) R: a language and environment for statistical computing. R Foundation for Statistical Computing, Vienna

Robbins RL, McCreery EK (2003) Acoustic stimulation as a tool in African wild dog conservation. Biol Conserv 111:263-267. https:// doi.org/10.1016/S0006-3207(02)00294-X

Šálek M, Červinka J, Banea OC, Krofel M, Ćirović D, Selanec I, Penezić A, Grill S, Riegert J (2014) Population densities and habitat use of the golden jackal (Canis aureus) in farmlands across the Balkan Peninsula. Eur J Wildl Res 60:193-200. https://doi.org/10.1007/ s10344-013-0765-0

Söderström B, Svensson B, Vessby K, Glimskär A (2001) Plants, insects and birds in semi-natural pastures in relation to local habitat and landscape factors. Biodivers Conserv 10:1839-1863. https://doi. org/10.1023/A:1013153427422

Spassov N (1989) The position of jackals in the Canis genus and lifehistory of the golden jackal (Canis aureus L.) in Bulgaria and on the Balkans. Hist Nat Bulgarica 1:44-56

Spassov N, Acosta-Pankov I (2019) Dispersal history of the golden jackal (Canis aureus moreoticus Geoffroy, 1835) in Europe and possible causes of its recent population explosion. Biodivers Data J 7: e34825. https://doi.org/10.3897/BDJ.7.e34825

Suter SM, Giordano M, Nietlispach S, Apollonio M, Passilongo D (2017) Non-invasive acoustic detection of wolves. Bioacoustics 26:237248. https://doi.org/10.1080/09524622.2016.1260052

Tóth T, Krecsák L, Szücs E, Heltai HG (2009) Records of the golden jackal (Canis aureus Linnaeus, 1758) in Hungary from 1800th until 2007, based on a literature survey. North-Western J Zool 5:386-405

Trbojević I (2016) Distribution of grey wolf (Canis lupus L., 1758) in Bosnia and Herzegovina. Glasnik Šumarskog Fakulteta Univerziteta u Banjoj Luci:41-49

Trbojević I, Trbojević T, Malešević D, Krofel M (2018) The golden jackal (Canis aureus) in Bosnia and Herzegovina: density of territorial groups, population trend and distribution range. Mamm Res 63:341-348. https://doi.org/10.1007/s13364-018-0365-1

Trouwborst A, Krofel M, Linnell JDC (2015) Legal implications of range expansions in a terrestrial carnivore: the case of the golden jackal (Canis aureus) in Europe. Biodivers Conserv 24:2593-2610. https://doi.org/10.1007/s10531-015-0948-y

Volk T (2010) Agriculture in the Western Balkan countries, studies on the agricultural and food sector in central and Eastern Europe, no. 57. Leibniz Institute of Agricultural Development in transition economies (IAMO), Halle (Saale)

Witmer FDW, O’Loughlin J (2009) Satellite data methods and application in the evaluation of war outcomes: abandoned agricultural land in Bosnia-Herzegovina after the 1992-1995 conflict. Ann Assoc Am Geogr 99:1033-1044

Zurovec O, Vedeld OP, Sitaula KB (2015) Agricultural sector of Bosnia and Herzegovina and climate change - challenges and opportunities. Agriculture 5:245-266. https://doi.org/10.3390/agriculture5020245

Zuur AF, Ieno EN, Elphick CS (2010) A protocol for data exploration to avoid common statistical problems. Methods Ecol Evol 1:3-14. https://doi.org/10.1111/j.2041-210X.2009.00001.x

Publisher's note Springer Nature remains neutral with regard to jurisdictional claims in published maps and institutional affiliations. 